\title{
Delovanje centrov za socialno delo v času prvega in drugega vala epidemije covida-19
}

\begin{abstract}
Problemi, ki jih je povzročila epidemija covida-19, niso le zdravstveni, temveč segajo na več ravni družbenega in zasebnega življenja. Socialno delo bi moralo imeti v izrednih razmerah pomembno vlogo, da bi pripomoglo kustvarjanju ustreznih odzivov na nove družbene okoliščine. Rezultati raziskave Socialno delo včasu covida-19, izvedene vobdobju od marca 2020 do aprila 2021 z uporabo mešanih metod zbiranja podatkov, kažejo, da socialno delo ni imelo vidne vloge pri načrtovanju ukrepov in da so bili socialni učinki vladnih ukrepov spregledani. Centri za socialno delo v Sloveniji niso bili pripravljeni na veliko naravno katastrofo in niso imeli izdelanih ustreznih praks za delo $v$ izrednih razmerah. Napodlagianalize podatkoviz raziskave in zupoštevanjem znanstvenih izhodišč za socialno delo $v$ izrednih razmerah lahko smiselno oblikujemo smernice za delovanje socialnih služb v času epidemije covida-19. Predvsem je pomembno spoštovanje in omogočanje strokovne avtonomije, pomemben je način vodenja, ki naj bo horizontalen in naj omogoča povezovanje in samoorganizacijo zaposlenih, saj to omogoča hitro in učinkovito dogovarjanje med zaposlenimi, to pa veča tako dostopnost do storitev kot zadovoljstvo zaposlenih. V raziskavi se je pokazalo, da so tisti centriza socialno delo, ki so delovali vskladu s to usmeritvijo, delovali boljodprto za uporabnike storitev in opaznega je bilo več proaktivnega in neposrednega socialnega dela z ljudmi.
\end{abstract}

Ključne besede: izredne razmere, strokovna avtonomija, uporabniki storitev, vodenje, krizno upravljanje, socialne delavke.

Dr. Nina Mešl je na Fakulteti za socialno delo docentka za področje socialnega dela. Raziskovalno in pedagoško se ukvarja s procesi podpore in pomoči v socialnem delu, s posebnim zanimanjem za socialno delo z družino. Kontakt: nina.mesl@fsd.uni-lj.si

Dr. Vesna Leskošek je na Fakulteti za socialno delo redna profesorica za področje socialnega dela. Raziskovalno in pedagoško se ukvarja s področjem zaščite otrok, nasilja, spola in družbenih neenakosti. Kontakt: vesna.leskosek@fsd.uni-lj.si

\section{Functioning of social work centres during the first and second wave of Covid-19 epidemic}

Problems caused by the Covid-19 epidemic are not only health-related, but stretch to multiple levels of social and private life. Social work should play an important role in extreme circumstances and contribute to creating appropriate responses to new social situations. Results of "Social work in time of Covid-19 « research, carried out from March 2020 till April 2021 using mixed methods of data collection, show that social work didn't play a visible role in designing anti-Corona measures and that social consequences of governmental measures were overlooked. Social work centres in Slovenia were not ready for a major natural disaster and didn't have appropriate practices in store for dealing with extreme circumstances. Based on analysis of data from the research, and considering scientific framework for doing social work in extreme situations, meaningful guidelines for operating social services in time of Covid-19 epidemic can be formed. Mainly, professional autonomy should be respected and made possible. Leadership style should be horizontal enabling connection and self-organisation of the employed as this increases availability of services to users as well as satisfaction of the employed. The research shows that those social work centres that functioned according to this guideline, were able to conduct their work more openly for service users. As a consequance, more proactive and direct social work with people was possible.

Key words: extreme circumstances, professional autonomy, service users, leadership, crisis management, social workers.

Nina Mešl, PhD, is an Assistant Professor at the Faculty of Social Work, University of Ljubljana. Her research and teaching interests include processes of support and help in social work, more specifically social work with family. Contact: nina.mesl@fsd.uni-lj.si

Vesna Leskošek, PhD, is a Professor at the Faculty of Social Work, University of Ljubljana. Her research and teaching interests include protection of children, violence, gender, and social inequalities. Contact:vesna.leskosek@fsd.uni-lj.si 


\section{Uvod}

Pandemija covida-19 je v letih 2020 in 2021 zaznamovala svet. Posledice se kažejo na različnih ravneh, na številnih življenjskih področjih, pri različnih skupinah ljudi. Ker gre za pojav virusa, ki je povzročil veliko obolelih in obremenil zdravstveni sistem, je v preteklih dveh letih zdravstvena stroka usmerjala ukrepe za omejitev epidemije, vlada pa na podlagi njihovih priporočil in po lastni oceni stanja sprejemala omejitvene ukrepe. Ti so vplivali na zasebna življenja in javno delovanje ljudi. Izhajajoč iz mednarodne definicije socialnega dela (Global definition of social work, b.d.) naj bi v izrednih razmerah imelo pomembno vlogo tudi socialno delo, saj ima znanja in spretnosti, da $\mathrm{v}$ času velikih družbenih izzivov pomembno pripomore k ustvarjanju ustreznih odzivov na nove družbene okoliščine.

To ugotavljajo tudi slovenske avtorice in avtorja (Rode, Zidar, Lamovšek, Škerjanc in Urek, 2010), ki menijo, da je za podporo, informiranost, povečanje gotovosti ljudi v kriznih razmerah zelo pomembna kontinuirana navzočnost strokovnih delavk na terenu. Le tako lahko zmanjšajo škodo in se odzovejo na potrebe ljudi, ki so jih druge službe obšle. Če je pomoč nestrokovna, nenačrtovana, politično motivirana, lahko še poveča nesorazmerja moči v skupnosti, manj vplivne skupine postanejo dvojne žrtve.

V članku analizirava vlogo socialnega dela v Sloveniji pri reševanju problemov, ki jih je povzročila epidemija na ravni družbenega in zasebnega življenja ljudi. Ugotavljava, da socialno delo ni imelo vidne vloge in se večinoma ni nemudoma odzvalo na vse večje potrebe ljudi po podpori in pomoči v teh, za marsikoga hudih časih, vendar ugotavljava tudi, da so se centri za socialno delo v nekaterih okoljih vključili v aktivnosti civilne zaščite in soustvarjali odzive na potrebe ljudi na lokalni ravni in da so se v nekaterih lokalnih okoljih zelo hitro organizirali za neposredno osebno delo z ljudmi.

Ne smemo spregledati tudi pomembne vloge, ki so jo imele socialne delavke v domovih za stare ljudi, šolah, vrtcih in zdravstvenih službah in seveda tudi v nevladnih organizacijah. Vendar pa so rezultati v članku predstavljene raziskave pokazali, da je v veliko lokalnih okoljih vloga socialnega dela ostala nevidna in marginalna, kljub povečanim potrebam po pomoči in podpori. Skrb zbujajoča je tudi odrinjenost socialnega dela iz odločanja o ukrepih na vseh ravneh, od lokalne do državne, zato so ostale potrebe ljudi skoraj povsem spregledane, saj je bil glavni poudarek na zdravstvenih ukrepih in ukrepih za omejitev gibanja. Vendar takšno stanje ni značilno le za Slovenijo. Na to opozarjajo tudi avtorice in avtorji po svetu, ki pozivajo k akciji, k temu, da socialno delo stopi iz ozadja, da se ga sliši v globalnem diskurzu pandemije (Amadasun, 2020; Walter-McCabe, 2020) in da podpre najranljivejše skupine ljudi (npr. Berg-Weger in Morley, 2020; Saltzman, Hansel in Bordnick, 2020).

Pandemija covida-19 je postavila socialne delavke čez noč v zelo drugačne institucionalne okvirje za opravljanje vsakdanjega dela, ki že od začetkov razvoja stroke temelji na vzpostavljanju odnosov z ljudmi s kompleksnimi psihosocialnimi problemi. Ti odnosi temeljijo na osebnem stiku in potekajo $\mathrm{V}$ okoljih, kjer ljudje živijo. V času epidemije so institucionalne okvirje soobli- 
kovali ukrepi, povezani s preprečevanjem širjenja virusa SARS-CoV-2, ki jih je oblikovala vlada. Posledice ukrepov so se hitro začele kazati na več ravneh (Dominelli, Harrikari, Mooney, Leskošek in Kennedy Tsunoda, 2020; Kerč, Krohne, Šraj Lebar in Štirn, 2021): izguba sredstev za preživetje in povečevanje revščine tudi pri prej materialno oskrbljenih ljudeh (SURS, 2021), izguba zaposlitve (ZRSZ, 2021) ali ukrepi čakanja na delo, ki so znižali dohodke ljudi ${ }^{1}$, povečevanje duševnih stisk ljudi, povečevanje nasilja v domačem okolju, kjer so žrtve predvsem ženske in otroci, povečanje števila femicidov, povečanje stisk zaradi izzivov organiziranja vsakdanjega življenja, skrbi in nege družinskih članov, šolanja otrok od doma, poglabljanje razlik med otroki zaradi zaprtja vrtcev in šol ipd.

V članku predstavljava del rezultatov kvalitativne in kvantitativne raziskave Socialno delo v času covida-19, ki smo jo na Fakulteti za socialno delo začeli izvajati marca 2020. Rezultati raziskave so obsežni, zato se v tem članku osredotočiva na delovanje centrov za socialno delo kot osrednjih socialnovarstvenih služb, ki bi morale biti vpete v lokalna okolja in se odzivati na raznovrstne in kompleksne potrebe ljudi v teh okoljih. Zanima naju odziv centrov za socialno delo in kako je način organizacije in vodenja pripomogel k možnostim socialnih delavk, da se odzivajo na potrebe ljudi. Zanima naju tudi, kako te ukrepe in način organizacije vrednotijo socialne delavke, kakšne so bile ovire in kakšne podpore za njihovo delo in katere etične dileme so se pojavljale. Na podlagi rezultatov bova na koncu opredelili tematske sklope, ki jih je v prihodnje treba upoštevati pri načrtovanju ukrepov za socialno delo v izrednih razmerah.

\section{Mednarodne izkušnje delovanja socialnega dela v času pandemije}

Pandemija covida-19 je sprožila več nepredvidljivih dogodkov na različnih družbenih področjih, z daljnosežnimi posledicami. Uredniki mednarodnega poročila o socialnem delu v času prvega vala covida-19 (Dominelli, Harrikari, Mooney, Leskošek in Kennedy Tsunoda, 2020) opozarjajo na velike moči pandemije z močnimi bio-fiziološko-psihološkimi učinki, ki lahko povzročijo številne družbene krize. Govorimo lahko o drastičnem razpadu družbenih sistemov, $v$ katerih so bila ogrožena tako načela delovanja sistemov kot tudi načini, kako se ljudje srečujejo in komunicirajo. Zaradi teh sprememb so se znašli socialni delavci in delavke pred številnimi izzivi in so se morali lotiti iskanja novih načinov sodelovanja z ljudmi (Pink, Ferguson in Kelly, 2020; McFadden idr., 2020; Harrikari, Romakkaniemi, Tiitinen in Ovaskainen, 2021). Pojavljala so se tudi številna etična vprašanja (Banks idr., 2020).

Družbeni nadzor nad ranljivimi skupinami ljudi in represivno delovanje proti njim se v času družbenih kriz navadno povečujeta in zaostrujeta. Zato je tudi $\mathrm{v}$ času pandemije ena glavnih nalog socialnega dela upoštevanje nacionalnih

Začasno denarno nadomestilo plače za izgubo zaposlitve v obdobju epidemije je znašalo 513,64 evrov bruto. 
in mednarodnih standardov, namenjenih zaščiti najranljivejših skupin ljudi, in varovanje njihovih temeljnih pravic. Vloga socialnega dela je bila v času prvega vala epidemije v državah po svetu različna (Dominelli, Harrikari, Mooney, Leskošek in Kennedy Tsunoda, 2020). Nenaden pojav velikega zdravstvenega problema je izzval socialno delo na več ravneh, od neposrednega sodelovanja $\mathrm{z}$ ljudmi do globalnih odnosov. Pandemija ni le razkrila že obstoječih problemov socialnega dela, temveč so se pojavili tudi novi. Kot temeljne šibkosti socialnega dela v času prvega vala epidemije na Finskem Harrikari, Romakkaniemi, Tiitinen in Ovaskainen (2021) navajajo neustrezno krizno upravljanje in komunikacijo, rigidne odnose vodij in omejeno infrastrukturo za opravljanje dela na daljavo, povečevanje napetosti $v$ delovnih timih, nove naloge, povezane s pandemijo, ki jih je določila administracija.

Tudi v Združenem kraljestvu na podlagi obsežne raziskave, opravljene med zaposlenimi v zdravstvu in socialnem varstvu, ugotavljajo, da je bilo vprašanje ustreznih organizacijskih odzivov in skrbi za izboljšanje komunikacije in povezanosti med zaposlenimi v času epidemije ključno (McFadden idr., 2020). Pomembni viri za dobro prakso socialnega dela v času epidemije so tudi strokovna refleksija in fleksibilnost, hitro prilagajanje na spremembe, uporaba strokovnega znanja in kompetenc, delo v skladu s poklicno etiko in spodbujanje strukturnega socialnega dela (Harrikari, Romakkaniemi, Tiitinen in Ovaskainen, 2021). Ob tem pa je bilo treba ugotoviti, kako ustvariti nove oblike sodelovanja z ljudmi, kjer sta bila še do pred kratkim ključna osebni stik in delo na terenu. Sprožala so se nova vprašanja, kako npr. zagotoviti zaščito otrok, vstopati v zasebnost ljudi in razvijati ustrezne, nove oblike digitalnega socialnega dela (Pink, Ferguson in Kelly, 2020).

\section{Socialno delo v času covida-19 v Sloveniji - raziskava}

O socialnem delu v času epidemije covida-19 so si mnogi ustvarili mnenje, ki lahko temelji na osebnih izkušnjah, spremljanju novic v medijih, ali ugibanjih, in ki lahko določa prepričanja o socialnem delu in socialnih delavkah. To mnenje je $v$ javnosti pogosto negativno, povezano predvsem $\mathrm{z}$ represivnimi ukrepi, denarnimi dajatvami in birokratizacijo socialnih služb. Redkeje v javnost prodrejo dobre izkušnje, ki bi spreminjale to podobo. Z raziskavo Socialno delo v času covida-19 smo želeli izvedeti, kaj se je dejansko dogajalo, kakšna je bila dostopnost storitev in odzivnost socialnih delavk na težave in potrebe ljudi $\mathrm{z}$ vidika strokovnih delavk in $\mathrm{s}$ tem prispevati $\mathrm{k}$ vidnosti socialnega dela.

Raziskavo sva zasnovali in izvedli Vesna Leskošek in Nina Mešl s Fakultete za socialno delo, pobudo pa je dal Timo Harrikari s Univerze iz Laponske. Že na začetku prvega vala epidemije naju je povabil v mednarodno skupino raziskovalk in raziskovalcev, ki naj bi zbrala dnevniške zapise socialnih delavk. Pozneje sva te zapise dopolnili s spletno anketo in s poglobljenimi intervjuji, ki jih je poleg naju opravila še Valentina Celestina. Pri analizi podatkov sta se skupini pridružili Tadeja Kodele in Tamara Rape Žiberna, prav tako s Fakultete za socialno delo, ki sta v že tako obsežen raziskovalni 
material vključili še poročila mentoric študentk na praksi, za katere sta s pomočjo vodje Centra za praktični študij na Fakulteti za socialno delo pridobili privolitev. Raziskovanje je potekalo tako rekoč ves čas epidemije od marca 2020 do aprila 2021, od takrat pa podatke obdelujemo in analiziramo. $\mathrm{V}$ tem članku bova uporabili del tega gradiva, ki ga podrobneje opisujeva $\mathrm{v}$ nadaljevanju.

\section{Uporabljena metodologija in proces zbiranja podatkov}

Za namen tega članka izhajava iz dveh sklopov raziskovanega gradiva. Prvo gradivo so dnevniški zapisi strokovnih delavk z različnih področij socialnega dela. K pisanju dnevnikov sva povabili 59 strokovnih delavk in delavcev ter za pomoč pri razširjanju vabila prosili Društvo socialnih delavk in delavcev Slovenije, končnega števila ljudi, ki jih je vabilo doseglo, zato ne poznava. Javilo se je 23 strokovnih delavk, na koncu pa sva pridobili 16 dnevniških zapisov. Sprva smo se usmerili na populacijo socialnih delavk, a so se na centrih za socialno delo za sodelovanje odločile tudi strokovne delavke drugih poklicev. Pisanje dnevnikov je trajalo od marca do konca maja 2020. Za pisanje dnevnika nisva dali navodil, udeleženke sva povabili k opisovanju dela, dilem, rešitev, tudi čustvenega doživljanja sprememb, razmišljanj, izkušenj, zgodb, osebnih refleksij o dogajanju, odprtih vprašanj. Obliko in vsebino sva prepustili piskam, zato so dnevniki zelo različni in ponujajo zelo bogat nabor podatkov. Za uporabo podatkov sva pridobili podpisane obrazce soglasja, v skladu z etiko v raziskovanju, ki je določena s pravili Univerze v Ljubljani. Ker v članku predstavljava rezultate za centre za socialno delo, sva v analizo vključili 11 dnevniških zapisov strokovnih delavk s tega področja (7 socialnih delavk, 3 pravnice, 1 psihologinja).

Druga metoda zbiranja podatkov je bila kvantitativna, in sicer spletna anketa, s katero sva želeli pridobiti več podatkov o delovanju centrov za socialno delo, saj so dnevniški zapisi kazali na razlike in so se nanašali le na obdobje prvega vala epidemije. Populacija raziskave so bili vsi zaposleni na centrih. Uporabili sva več pristopov za vključitev v raziskavo, ker ne obstaja enoten register zaposlenih. Vabilo sva poslali na 796 naslovov, ki sva jih pridobili na spletnih straneh centrov za socialno delo, tudi koordinatorkam s področja nasilja, invalidnosti in duševnega zdravja, ki sva jih pridobili s spletne strani Skupnosti centrov za socialno delo. E-pošta ni bila dostavljena 57 osebam s seznama 796 naslovov. Podatkov nisva mogli pridobiti za te enote centrov za socialno delo: Ormož, Ptuj, Izola, Piran, Sežana, Kočevje in Ribnica, ker seznam zaposlenih s teh enot ni bil dostopen na spletnih straneh. Na te enote sva poslali vabilo tako, da sva prosili osebo, ki sva jo poznali, da razpošlje vabilo drugim zaposlenim in vabilo poslali tudi na splošni elektronski naslov posameznega centra, zato ne moreva z gotovostjo vedeti, koliko zaposlenih je vabilo doseglo. Poleg tega sva posredovali vabilo k izpolnjevanju vprašalnika na Facebook skupino Socialci (socialni delavci).

Vprašalnik sva oblikovali v programu $1 \mathrm{ka}$. Vprašalnik je sestavljen iz 18 vprašanj, od tega 13 obveznih in 5 neobveznih. Med neobveznimi je bila 
večina odprtih, eno pa se je nanašalo na center za socialno delo, s katerega anketirani prihajajo. To vprašanje je bilo neobvezno, ker pri ljudeh lahko povzroči nezaupanje glede anonimnosti. Pomembno je bilo primerjati stanje prvega in drugega vala epidemije, zato sva spraševali po organizaciji dela in stikih med zaposlenimi ter $\mathrm{z}$ uporabnicami in uporabniki storitev $\mathrm{v}$ obeh fazah epidemije. Prvo fazo sva opredelili od sredine marca do konca maja 2020, drugo pa od sredine oktobra do začetka decembra 2020, ko sva pošiljali vabilo za izpolnjevanje spletnega vprašalnika. Anketa je bila aktivirana od 7. 12. do 21. 12. 2020, torej 14 dni. Vprašalnik je veljavno izpolnilo 294 strokovnih delavk.

\section{Obdelava podatkov}

Kvalitativne podatke sva analizirali s pomočjo računalniškega programa za analizo kvalitativnih podatkov MAXQDA (kategorizacijo besedila v tematske kode; splošna zastopanost različnih kod v celotnem besedilu; analiza kodirnega besedila). Opravili sva vsebinsko analizo besedila. Metoda se usmerja $\mathrm{v}$ raziskovanje relacij med določenimi pojmi ali koncepti $\mathrm{v}$ besedilu in med besedili. Opravili sva tudi tematsko analizo in se osredotočili na identificiranje vzorcev oziroma tem v besedilu. Glede na to, da za analizo uporabljava dnevniške zapise, je bilo pomembno analizirati tudi osebno izkušnjo udeleženk raziskave, zato je delno analiza tudi interpretativno fenomenološka. Nenadni izbruh koronavirusne bolezni je namreč fenomen, ki sproža povsem nove izkušnje tako na osebnem kot na poklicnem področju (McFadden idr., 2020; BASW, b.d.).

Kvantitativne podatke sva analizirali s pomočjo računalniškega programa $1 \mathrm{ka}$, ki omogoča delno obdelavo podatkov, in jo nadgradili z uporabo SPSS. To analizo je opravila Tamara Rape Žiberna.

Rezultate predstavljava po tematskih sklopih, ki so se ob analizi, glede na raziskovalna vprašanja, pokazali za relevantne.

\section{Izkušnje socialnih delavk o socialnem delu v času covida-19 - predstavitev rezultatov}

\section{Splošne spremembe $v$ delovanju centrov za socialno delo v različnih obdobjih epidemije}

Največ sprememb in potreb po hitrih odzivih in reorganizaciji utečenih delovnih procesov se nanaša na obdobje prvega vala epidemije, ki ga lahko razdelimo v tri podobdobja: začetki okužb, epidemija in sproščanje ukrepov.

Čas začetka okužb so strokovne delavke doživljale kot obdobje negotovosti ob pričakovanju virusa, kazala se je potreba po spreminjanju običajnih navad v odnosih (npr. rokovanje ob začetku timskega sestanka, ob sprejemu uporabnika). Bilo je veliko novih in splošnih informacij in navodil, ki niso bila dovolj konkretna za ravnanja zaposlenih, razen higienskih ukrepov, ki jih je oblikoval Nacionalni inštitut za javno zdravstvo. Veliko pozornosti je bilo usmerjeno v 
spremljanje poročil o širjenju okužb. Ta so povzročila strah in nelagodje tudi med zaposlenimi. To se je kazalo v nezaupanju znotraj kolektivov glede tega, kdo je okužen, kdo ravna dovolj odgovorno. Predvsem so bili izpostavljeni ljudje, ki so zimske počitnice preživeli v tujini. Z novimi razmerami v družbi in strahom pred okužbo je bilo povezano tudi vprašanje pridobivanja ustrezne zaščitne opreme. Pojavljala so se temeljna eksistenčna vprašanja.

[...] v prvih tednih strah, negotovost v prvi vrsti zase, za svojo družino, otroke, za lastno eksistenco, dohodke, delo, šolske obveznosti, svoje bližnje in drage. (StD5.82)

Strokovne delavke so bile ob lastnih stiskah zaskrbljene tudi za uporabnike storitev. Zavedale so se, da številni uporabniki, ki se že ob običajnih družbenih okoliščinah srečujejo s kompleksnimi problemi, lahko v obdobju negotovosti glede širjenja virusa še težje sprejemajo ukrepe in omejitve. Prevladovalo je tudi zavedanje, da so nove okoliščine prispevale k negotovostim in omejitvam, kar je ljudi povezovalo na nov način.

V drugi vrsti za naše uporabnike, njihove družine, ki se že tako ali tako srečujejo z drugačnimi izzivi kot jaz in so za to slabše opremljeni. Spoznanje, da smo vsi v istem, za vse veljajo enake omejitve, enaka navodila in vsak se »bori« po svoje. (StD5.8)

Ukrepe glede organizacije dela in omejitev v stikih $v$ obdobju epidemije ${ }^{3}$ so posredovala pristojna ministrstva in Nacionalni inštitut za javno zdravje. Zaposleni so morali spremljati številna obvestila, da so lahko načrtovali svoje delo. Prejeta navodila jim je posredovalo vodstvo, včasih pa so bila nasprotujoča si in nenatančna. Strokovne delavke so poskušale opravljati svoje delo ob navodilih, a hkrati se je bilo treba človeško, strokovno in hitro odzivati na nove okoliščine, ki jih navodila niso urejala.

Natančnih navodil za delo ne moremo pričakovati od zgoraj navzdol. Pomembneje je, da se delo ustvarja skupaj z ljudmi, ki nas potrebujejo zaradi sedaj povsem novih situacij, ki jih prej nismo poznali. (StD7.13)

Dober primer za ponazoritev razkoraka med navodili in potrebami ljudi je ukrep Ministrstva za delo, družino, socialne zadeve in enake možnosti, da kriznega dodatka $\mathrm{k}$ denarnim pomočem na centrih za socialno delo ne smejo izplačati v funkcionalni obliki, temveč na tekoči račun. To je strokovnim delavkam povzročalo velike težave. Za mnoge uporabnike je to namreč pomenilo, da si morajo na novo odpreti tekoče račune, to pa je sprožilo veliko nezadovoljstva, stisk, tudi jeze.

S tem bodo težave (odpori uporabnikov, nezadovoljstvo, občutek, da jih ne razumemo, tudi jeza), kakor smo se pogovarjale s strokovnimi delavkami s tega področja, ker imajo ljudje razloge, zakaj ne želijo imeti prejemkov na TRR (v glavnem je to zaradi strahu pred izvršbami zaradi dolgov ali zato, da jim ne odtegnejo obresti ipd. v povezavi z izvršbami). Dogovor je bil, da

2 Dnevniški zapisi so šifrirani na način, da je najprej označena zaporedno številka strokovne delavke/StD (npr. dnevniški zapis StD5), nato sledi zaporedna številka kodiranega dela dnevniškega besedila (npr. 8).

3 Več o procesih dela med epidemijo piševa po različnih tematskih sklopih v nadaljevanju. 
strokovne delavke vse te uporabnike pokličejo danes (ali jutri) in jim vse to razložijo (ter podajo tudi informacijo, da Banka Koper odpira osnovne račune, saj sicer ostale banke tega ne želijo). (StD1.56)

$V$ tretjem obdobju sproščanja ukrepov so se zaposleni pričeli vračati na delovna mesta, sprostili so se tudi ukrepi in posledično je bilo več osebnih stikov med zaposlenimi. Strokovne delavke so se ob sproščanju ukrepov začele dogovarjati za osebne pogovore z uporabniki, ki so do tedaj potekali večinoma po telefonu. Ob tem je bilo še vedno treba upoštevati nekatere omejitve, povezane z ukrepi za preprečevanje širjenja virusa.

Včeraj sem imela že prvo pokoronsko obravnavo na sodišču, režim je bil zelo strog. (StD11.71)

Kljub zadovoljstvu ob sproščanju ukrepov, ki je bilo povezano z vzpostavljanjem osebnega stika in ponovnim vzpostavljanjem prejšnje strukture dela, je preklic epidemije pomenil tudi krčenje nekaterih pravic za ljudi v materialnih stiskah.

$S$ preklicem epidemije se odvzema pomoč in poglablja revščina. Vlada na ta način sporoča, da se mora vsak znajti nekako po svoje. (StD7.23)

Značilnosti odzivov socialnega dela $v$ drugem valu podrobneje predstavljava v nadaljevanju. Na splošno pa rezultati kažejo, da je bilo v tem obdobju na področju socialnega dela manj strahu zaradi nepoznavanja virusa SARS-CoV-2, tudi izkušnje iz prvega vala so pripomogle k večji odzivnosti in dostopnosti socialnega dela.

\section{Pomen ustrezne organizacije vizrednih razmerah}

V času epidemije covida-19 se je bilo treba na novo organizirati. Potrebni so bili takojšnji odzivi pri oblikovanju novih institucionalnih okvirjev in rešitev, ki so jih zaposleni pričakovali v najkrajšem možnem času. Analiza dnevniških zapisov pokaže, da je bila največja ovira za hitro odzivanje pomanjkanje načrtov za ravnanje v izrednih razmerah. Centri za socialno delo so na začetku epidemije večinoma zaprli vrata za uporabnike. Tudi zaposleni so lahko omejeno opravljali delo v prostorih centrov. Ponekod so zelo hitro, drugje sčasoma, organizirali dežurstva, da bi z zmanjšanjem števila strokovnih delavk v prostorih centrov za socialno delo preprečevali širjenje okužb. V tem obdobju so obstajale različne kombinacije izvajanja dela, to so delo na delovnem mestu $s$ koriščenjem dopusta ali čakanjem na delo, manj je bilo možnosti kombiniranja z delom od doma. Počasi, ko se je pokazalo, da epidemija ne bo trajala le kratko obdobje, so iskali načine, kako doseči uporabnike ${ }^{4}$. Ker večinoma ni bilo osebnega stika, je bil ta mogoč le z uporabo informacijsko-komunikacijske tehnologije. Tehnična nepripravljenost za oddaljen dostop na centrih za socialno delo je oteževala delo v izrednih razmerah.

Spoznala sem, da na delo od doma nismo pripravljeni, nismo mu dorasli. Na hipe se mi je zdelo, da smo leta 2020, a zdi se, da smo ostali v kameni dobi. Zraven sem imela kot primerjavo partnerja, ki sicer dela v gospodar- 
stvu. Videla sem, kako poteka njegovo delo od doma in kako moje. Rabim dostop do računalnika, rabim dostop do pošte. Vsaj to. Sicer je delo od doma nemogoče. (StD4.9)

Zaradi manjšega števila zaposlenih, ki so lahko opravljali delo na centrih za socialno delo, ter povečanega števila klicev in elektronskih sporočil se strokovne delavke niso mogle takoj odzvati. To je povzročalo nezadovoljstvo in večalo stiske uporabnikov in tudi strokovnih delavk. Hitre in ustrezne odzive so omogočali fleksibilnost organiziranja znotraj posameznega zavoda ter dobro sodelovanje in podpora med zaposlenimi. Pomembno je bilo usklajevanje med strokovnimi delavkami, ki je bilo opazno predvsem tam, kjer je bilo vodstvo podporno in prav tako usmerjeno na iskanje rešitev. Načini organiziranja so se spreminjali s časom trajanja epidemije, s pridobivanjem izkušenj in novih dognanj o virusu.

Veliko sprememb $\mathrm{v}$ organizaciji in dostopnosti socialnega dela uporabnikom centrov za socialno delo je vidnih v drugem valu epidemije. Z anketnim vprašalnikom smo med strokovnimi delavkami centrov preverjale stopnjo zadovoljstva z načinom organiziranja dela (graf 1 ).

Zadovoljstvo z organizacijo dela - Način organiziranja dela

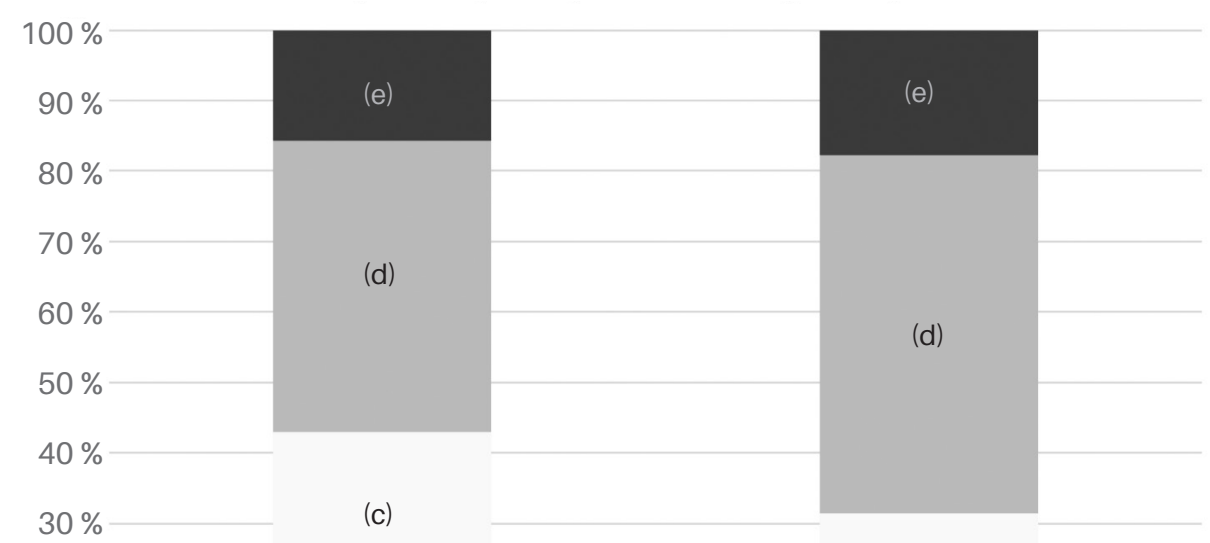

(c)
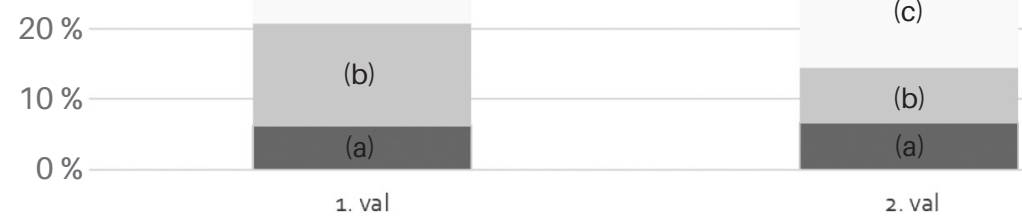

(a) Zelo nezadovoljen_na

(b) Nezadovoljen_na

(c) Niti niti

(d) Zadovoljen_na

(e) Zelo zadovoljen_a

Graf 1: Zadovoljstvo z organizacijo dela.

Med prvim in drugim valom je nekaj razlik, in sicer se je odstotek zelo zadovoljnih nekoliko povečal, če pa k temu prištejemo še zadovoljne, lahko ugotovimo že občutno izboljšanje razmer. Skupaj jih je bilo v drugem valu zadovoljnih in zelo zadovoljnih $68,7 \%$, v prvem valu pa jih je bilo $56,8 \%$. V drugem valu se je tudi nekoliko povečal odstotek zelo nezadovoljnih, vendar se je skupaj z nezadovoljnimi znižal. $V$ prvem valu je bilo nezadovoljnih in zelo nezadovoljnih $21 \%$, v drugem valu pa $14,4 \%$. Povečanje deleža zelo nezadovoljnih kaže, 
da se ponekod razmere niso izboljšale; nekatere strokovne delavke so imele informacije o tem, da je na drugih centrih za socialno delo bolje, zato so bile še bolj nezadovoljne. 0 tem v odprtih vprašanjih ankete poročajo tisti, ki so med epidemijo zamenjali službo in imajo izkušnjo teh razlik.

\section{Potrebe, težave in izzivi ljudi v času epidemije}

Kljub epidemiji in izzivom z opravljanjem socialnega dela v spremenjenih institucionalnih okvirih, ki so jih določali ukrepi za preprečevanje širjenja virusa, so ljudje seveda še vedno potrebovali podporo in pomoč. Potrebe so se na nekaterih področjih povečale oz. so se pojavile tudi nove, povezane z ukrepi, šolanjem in delom na daljavo. $V$ dnevniških zapisih so strokovne delavke omenile povečane potrebe po podpori za šolsko delo in učni pomoči.

Kličem starša, saj so nas iz šole obvestili, da otrok ne dela doma dovolj za šolo ... RES??? Kako jim naj dopovem (šoli, učiteljem, šolski svetovalni delavki), da otroku oče (mama je umrla 2 leti nazaj) ne zna in ne zmore pomagati, tudi sicer samo površinsko vpraša in dejansko ne spremlja, koliko je narejeno in koliko ni. Otroci v 8. razredu pa potrebujejo nenehne spodbude in nadzor, malo jih zmore samodisciplino $\mathrm{v}$ tolikšni meri, da res delajo za šolo, poleg prižganega računalnika, ki vabi v virtualni svet. $\mathrm{S}$ soglasjem očeta pokličem še otroka, ga povprašam, kako mu gre, ga poskušam spodbuditi za šolsko delo, vsaj v minimalnem obsegu, in tisto, kar je res nujno. Dogovoriva se, da ga ponovno pokličem po počitnicah in skupaj preveriva, kako mu gre. (StD5.18)

Povečalo se je nasilje v domačem okolju, težave so nastajale v zvezi z izvajanjem stikov po razvezi, s skrbstvenim delom za družinske članice in člane, $\mathrm{z}$ zagotavljanjem varstva otrok ipd. Pojavilo se je več napetosti v odnosih zaradi karantene.

Pri nekaterih se je že pojavila napetost $\mathrm{v}$ družinskem okolju zaradi karantene. Predvsem je to zaznati pri družinah, ki živijo v bloku, saj so še toliko bolj omejeni v gibanju, stanovanja so majhna, družine pa številčne, zato so se začela trenja in kreganje. (StD3.16)

Težko je bilo usklajevati poklicno in družinsko življenje. Ljudje so bili osamljeni, počutili so se utesnjene. Opazen je bil tudi strah pred okužbo z virusom.

$\mathrm{V}$ anketnem vprašalniku smo strokovne delavke vprašali, koliko so na njihovem delovnem področju izražene potrebe ljudi in kako jim jih je uspelo zadovoljiti. Iz grafa 2 je razvidno, da v nekaterih primerih strokovne delavke niso imele informacij o dogajanju na terenu ali pa so jih imele, vendar se s tem niso ukvarjale zaradi ovir v stikih z uporabniki in uporabnicami ali zaradi drugih institucionalnih ovir, npr. zaradi zaprtosti in otežene dostopnosti do drugih služb. Eno od teh področij je podpora ljudem, ki potrebujejo oskrbo, ali pa podpora svojcem, ki skrbijo za člana družine. Pri problemu lakote so mnenja izrazito polarizirana, približno $30 \%$ strokovnih delavk meni, da to ni problem, nekaj več kot $20 \%$ pa o tem nima informacij. Še največ rešenih zadev je bilo pri potrebah po denarnih pomočeh ali pri otrocih, ki so potrebovali pomoč pri šolanju. Strokovne delavke so v odprtih odgovorih 
poudarile, da nimajo kaj ponuditi okuženim osebam, ki so v karanteni in nimajo osebne mreže opore, omenjale so problem nujnih prevozov, ker ni bilo javnega prevoza, tudi taksisti so imeli omejitve. Več težav je bilo v zvezi $\mathrm{z}$ urejanjem nujnih dokumentov, zdravstvenega zavarovanja ipd. Strokovne delavke so bile omejene pri svetovanju ob razvezah in pri stikih, omenjale pa so tudi veliko potrebo ljudi po človeški bližini in po pomoči pri vse večjih psihosocialnih stiskah.

Graf 2: Zaznane težave ljudi v času prvega in drugega vala epidemije skupaj.

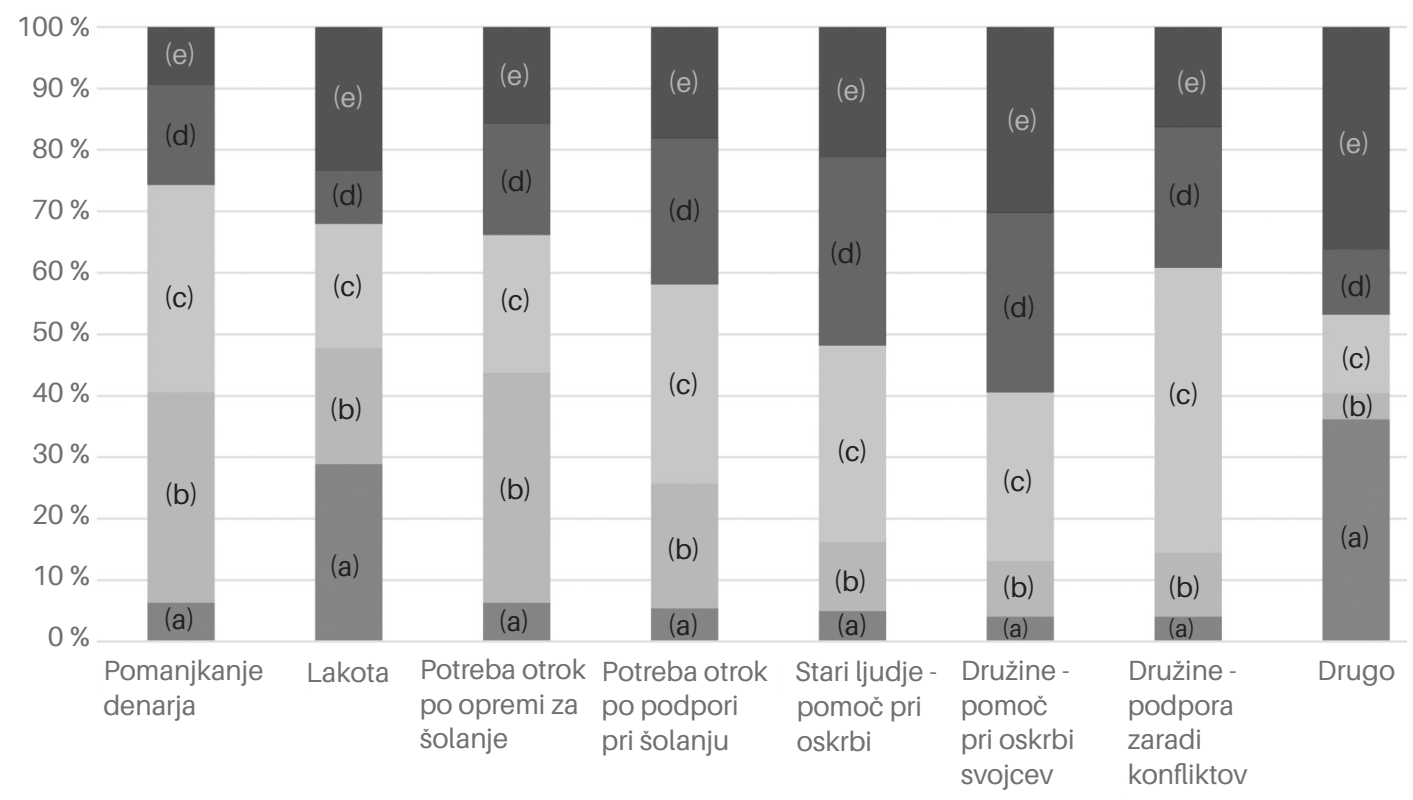

(a) Ni problem, (b) Je problem, in je rešeno, (c)Je problem, vendar na tem delam, (d) Je problem vendar, na tem ne delam, (e) Ne vem, nimam informacij

Nevladne organizacije so v času prvega in drugega vala epidemije opozarjale na povečano nasilje v domačem okolju (Nasilje in epidemija covida-19, b.d.). Povečano nasilje je pokazala tudi raziskava Kriminološkega inštituta o kriminaliteti v času epidemije (Plesničar, Drobnjak in Filipčič, 2020). Zanimalo nas je, kako to zaznavajo centri za socialno delo, saj so pomembni pri zaščiti žrtev nasilja. Rezultati pokažejo, da centri večinoma niso imeli informacij o tem, saj o tem ne ve nič tretjina v primeru nasilja nad ženskami, nekaj odstotkov več glede nasilja nad otroki, 57 \% glede nasilja nad ljudmi z oviranostmi, še več glede nasilja nad moškimi (62\%) in $44 \%$ glede nasilja nad starimi ljudmi. Da se je nasilje nad ženskami povečalo, meni $39 \%$ vprašanih (seštevek kategorij »se strinjam« in "se zelo strinjam«), da se je povečalo nasilje nad otroki, meni $38 \%$, za nasilje nad moškimi tako meni $9 \%$, nad starimi ljudmi $38 \%$ in nad ljudmi z oviranostmi $25 \%$. To so precej nizki odstotki, verjetno posledica neseznanjenosti s težavami ljudi na terenu zaradi prekinjenega stika. Vendar bi bilo napačno sklepati, da je problem popolnoma neobravnavan, saj so interventni timi delovali ves čas epidemije, tudi delavke na področju nasilja so imele stike z ženskami in otroki, žrtvami nasilja. Problem je bil večji pri nasilju, ki se je razvilo v času omejitev stikov in zaprtosti v okolje družine, saj so se konflikti lahko sprevrgli v nasilje. 
Graf 3: Zaznavanje nasilja.

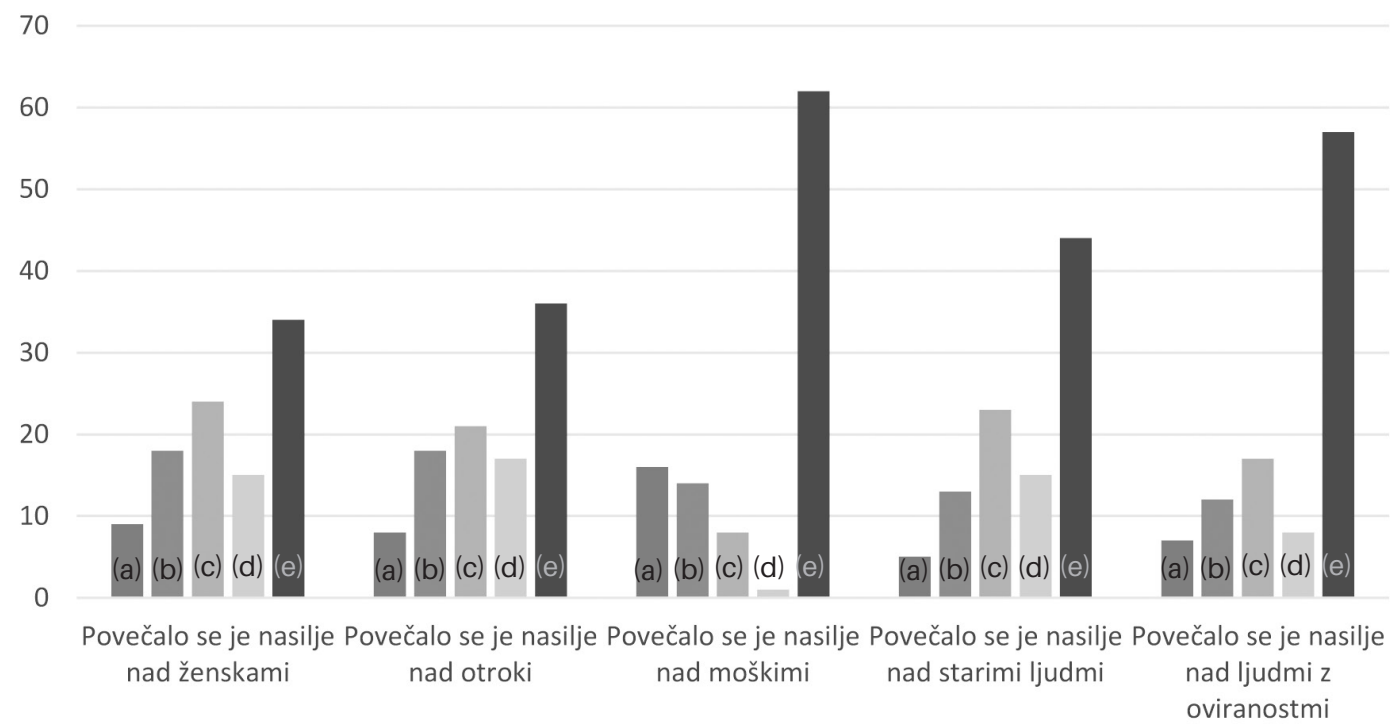

(a) Se ne strinjam, (b)Se delno strinjam, (c)Se strinjam, (d) Se zelo strinjam, (e) Ne vem

\section{Načini sodelovanja z ljudmi}

Glede na omejitve, povezane z epidemijo, je bilo treba iskati načine, kako opravljati socialno delo, ki po navadi temelji na osebnem stiku v pisarnah strokovnih delavk in na sodelovanju z ljudmi na terenu, v skupnosti, kjer živijo. Treba je bilo omogočiti nadaljevanje sodelovanja z ljudmi, ki so se srečevali s kompleksnimi problemi že pred epidemijo, in hkrati ugotoviti, kako vzpostaviti odnose z ljudmi, ki so v času epidemije na novo potrebovali pomoč socialnega dela.

Pri tem so se strokovne delavke, ki so pisale dnevnike, srečevale z ovirami, ki so bile povezane $\mathrm{z}$ načinom organiziranja dela in s predpisanimi ukrepi. Doživljale so stiske zaradi prepovedi opravljanja dela in pomanjkanja osebnega stika z uporabniki. Zaradi pomanjkanja osebnega stika, ki so ga večinoma strokovne delavke na centrih za socialno delo nadomestile s telefonskimi pogovori, jih je skrbelo, koliko lahko zaupajo v informacije, ki jih prejmejo po telefonu, in ali zares dosežejo ljudi, ki bi potrebovali njihovo pomoč.

Največje težave pa imam s sabo in z zaupanjem v informacije, ki mi jih po telefonu podajo ljudje iz družin, kjer nimajo urejenih medsebojnih odnosov, kjer je že bilo nasilje, kjer imamo informacije o prekomernem poseganju po alkoholnih pijačah. Skrbi me, kako je v tem času poskrbljeno za otroke, kako jim je doma. (StD2.10)

Strokovne delavke so se spraševale, koliko predpisani ukrepi zares omogočajo ustrezne odzive na potrebe ljudi. Številni ukrepi in navodila so potisnili socialno delo v ozadje, kot slikovito prikaže izsek iz dnevniškega zapisa, v katerem strokovna delavka odgovarja na vprašanje prioritet pri opravljanju socialnega dela.

Ena od sodelavk mi je povedala, da se je počutila kot zločinka, ker je danes imela v svoji pisarni gospo, s katero se je pogovarjala v okviru PSP-ja. Pozabila je namreč na varnostne ukrepe in gospo pripeljala v svojo pisarno. Šele ko je 
odhajala in jo je na hodniku druga sodelavka vprašala, če je spodnja pisarna za stranke zasedena in če se je o tem, da pripelje stranko v naše prostore, dogovorila [...], se je pravzaprav spomnila, da veljajo strogi ukrepi glede vstopa strank v prostore CSD. [...] kako se je že vsa ta »filozofija ustrahovanja in nadzorovanja v zvezi s korono « v nas zasidrala in s čim se pravzaprav ukvarjamo. Ni več bilo pomembno, da je uporabnica bila žrtev hudega nasilja. Pomembno je bilo, da je ne bi smeli pripeljati v prostore CSD-ja! (StD1.255)

Tudi v anketi smo spraševali o načinih sodelovanja z ljudmi, rezultate pa prikazujemo v grafih od 4 do 7. Redni, vsakodnevni osebni stik na centru za socialno delo je imelo v prvem valu le $14 \%$ strokovnih delavk, v drugem valu pa $26 \%$. Nikoli ni imelo osebnega stika v prvem valu $11 \%$ in redko $42 \%$, v drugem valu pa nikoli le še $6 \%$ in redko $26 \%$. Tu je bil sicer narejen velik napredek med obema valoma epidemije, vendar bi bilo treba raziskati, zakaj vendarle nekateri še vedno niso imeli osebnega stika ali pa so ga imeli zelo redko (skupaj je takih kar tretjina). Iz do zdaj dobljenih raziskovalnih podatkov nimamo ustreznih pojasnil. Še bolj drastične so številke pri terenskem delu, kjer je bilo na terenu v prvem valu le $3 \%$ strokovnih delavk in v drugem valu $4 \%$. Nikoli pa kar 36 \% v prvem valu in $28 \%$ v drugem valu. Če k temu prištejemo še tiste strokovne delavke, ki so bile na terenu redko, je tistih, ki skoraj niso bile na terenu, $\mathrm{v}$ prvem valu skupaj $81 \%$ in v drugem $66 \%$.

Čeprav je viden napredek med obema obdobjema, je pomanjkanje dela na terenu skrb zbujajoče. Poleg epidemičnih razlogov, ki so v ukrepih proti okužbam, se je tu relevantno vprašati, kako je s terenskim delom na centrih za socialno delo v običajnih časih, koliko so delavke sploh še navzoči v okoljih, kjer ljudje bivajo, in koliko delajo skupnostno, ne le individualno. Nekateri odprti odgovori nakazujejo, da je terensko delo na sploh redko in povezano z birokratskimi ovirami, kot so najave obiskov pri vodstvu, nujnost pridobiti dovoljenje za odhod na teren ipd. To kaže na izgubo strokovne avtonomije pri odločanju o metodah in načinih dela. Graf 6 pokaže na povečane stike po telefonu, kar je glede na omejitve nekaj povsem razumljivega. So pa tudi tukaj odprti odgovori pokazali na nekatere težave, in sicer, da nimajo vsi uporabniki storitev centrov za socialno delo telefonov in da so morale strokovne delavke uporabljati osebne telefone brez kritja stroškov: to je povzročalo omejitve ali pa zamere do delodajalcev. Ta problem je še izrazitejši pri uporabi informacijsko-komunikacijske tehnologije in smo ga podrobneje raziskovali s posebnim vprašanjem, rezultate pa prikazujemo v grafu 8.

Graf 4: Osebni stik na centrih za socialno delo. Graf 5: Obiski na terenu.

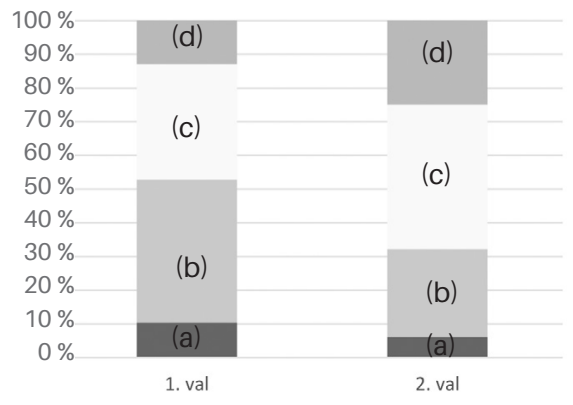

(a) Nikoli, (b)Redko, (c)Tedensko, (d) Vsak dan

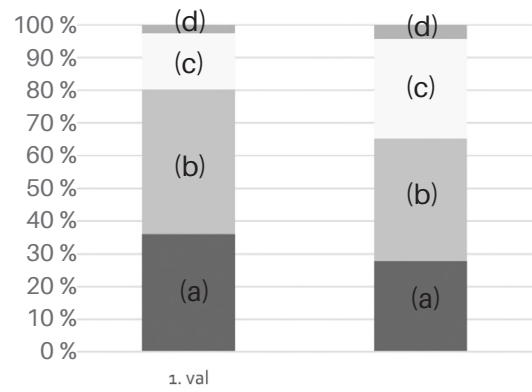

(a) Nikoli, (b)Redko, (c)Tedensko, (d) Vsak dan 
Graf 6: Telefonski stik.

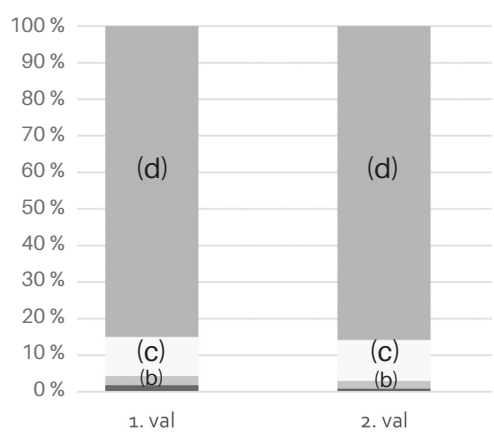

(a) Nikoli, (b) Redko, (c )Tedensko, (d) Vsak dan
Graf 7: Stik prek videokonference.

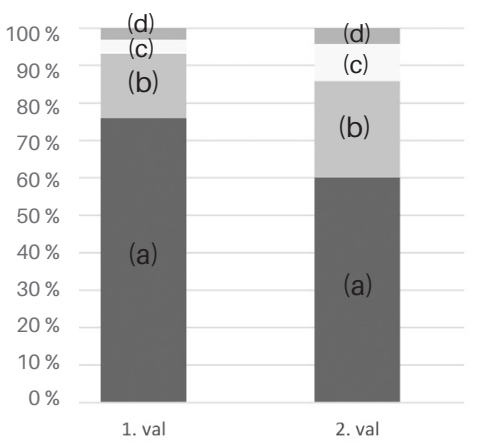

(a) Nikoli, (b) Redko, (c) Tedensko, (d) Vsak dan

Največje ovire pri uporabi telefona in programov za videoklic na računalniku ali aplikacij na telefonu so bile predvsem v zastareli ali manjkajoči opremi na centrih za socialno delo. Strokovne delavke niso imele prenosnih službenih telefonov, do stacionarnih pa niso mogle $v$ času, ko so imele prepoved prihoda na delovno mesto. Uporabljati so morale svoje, to pa je povečevalo njihove stroške zaradi množice telefonskih pogovorov, nekateri so bili zelo dolgi glede na stiske ljudi. Nekaj strokovnih delavk ni bilo usposobljenih za uporabo aplikacij za videoklice in tudi niso imele izobraževanja za uporabo. Odprti odgovori so pokazali, da je problem informacijsko-komunikacijske tehnologije na centrih za socialno delo sistemski, saj Ministrstvo za upravo ni zagotovilo dovolj IP naslovov, večina računalnikov pa je tako zastarelih, da nanje ni mogoče naložiti ustreznih programov. Na eni od predstavitev rezultatov tega raziskovalnega projekta je direktorica centra za socialno delo povedala, da so zaprosili za pet novih računalnikov, a niso dobili niti enega.

Graf 8: Ovire pri uporabi informacijsko-komunikacijske tehnologije.

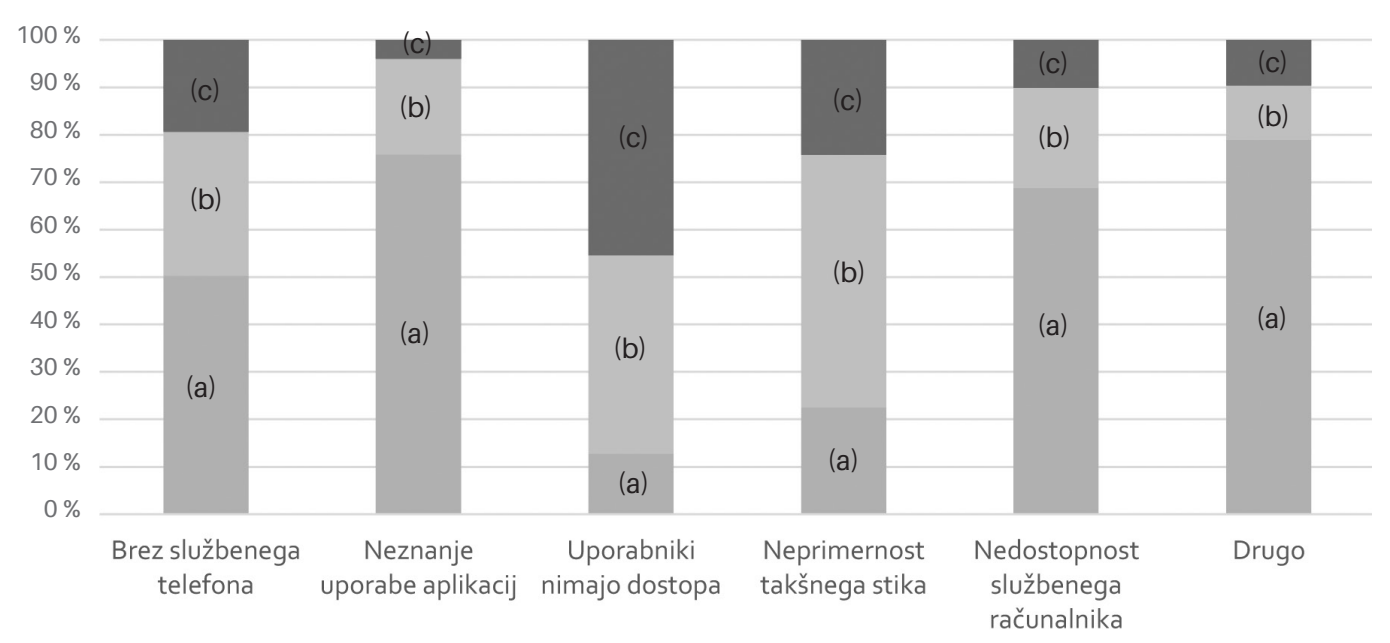

(a) Ni ovira, (b) Je delno ovira, vendar so rešitve, (c) Je resna ovira

Problem pomanjkanja tehnologije kaže na sistemske ovire v delovanju centrov za socialno delo, ki ima lahko usodne posledice za socialno delo. $\mathrm{V}$ času epidemije je bilo namreč hitro jasno, da je treba opremiti bolnišnice, če želi- 
mo rešiti življenja ljudi, to zavedanje pa je popolnoma umanjkalo, ko je šlo za področja zunaj zdravstva, zato so lahko socialne posledice epidemije večje kot zdravstvene (Lobnik, 2020; Ronchi in Majdič, 2021). Javno so bili sicer opisani problemi glede šolanja otrok na daljavo, saj mnogi otroci nimajo računalnika, starši pa so računalniško nespretni, zato otrokom niso mogli pomagati pri šolanju od doma. Ta problem je bil akuten in je bil le delno rešen. Ko pa gre za centre za socialno delo, problem ni bil problematiziran in se zanj ni iskalo rešitev. Tu zavedanja o pomenu socialnega dela sploh ni bilo, saj se na pristojnih ministrstvih niso ukvarjali z alternativnimi rešitvami za omogočanje reševanja stisk in težav ljudi, ker je bil običajni stik zelo oviran zaradi prepovedi osebnih stikov in terenskega dela. Iskanja za rešitev tega problema ni mogoče preložiti na vodje centrov za socialno delo ali celo na socialne delavke, čeprav se je zgodilo prav to. Posledica tega so bile številne dileme, tudi etične.

\section{Etične dileme strokovnih delavk}

Nekateri ukrepi so (nesmiselno) omejevali delo zaposlenih in odzivanje na potrebe uporabnikov. Čeprav so zaposleni želeli ravnati odgovorno, so imeli tudi dileme, povezane $\mathrm{z}$ omogočanjem pomembnih izkušenj uporabnikom, ki povečujejo kakovost življenja. Zaradi predpisanih omejitev so strokovne delavke morale začeti odločati, komu bodo zagotovile ustrezno podporo.

Ob navedenem razmišljam, kaj so nujni in kaj nenujni uporabniki (o čemer sem se sicer že začela spraševati takoj, ko smo ob izbruhu epidemije dobili navodila, da delamo samo nujne zadeve). Čeprav izvajanje storitve osebna pomoč težko uvrstim med nujna opravila (opravila zaradi življenjske ogroženosti, ogroženosti otrok, ostarelih itd.), je za marsikaterega mojega uporabnika njegova težava, zaradi katere prihaja na svetovalne pogovore, zanj nujna zadeva in je težko prenašal nezmožnost osebnih stikov.(StD6.23)

Pojavljale so se dileme, povezane z vzpostavljanjem osebnih stikov z uporabniki in upoštevanjem drugih navodil, ki posegajo v njihova življenja.

Danes bi morala na precej terenov. Ne vem, ali smem ali ne. Nekako se v sebi odločim: tereni so za moje delo nujni. Bom previdna. Odtehtalo je to, da dosti lažje delam, če opravim vsaj prvi obisk na domu. (StD4.45)

Strokovne delavke so imele tudi dileme, povezane z usklajevanjem dela in družinskega življenja. Če so bile doma z otroki, ki niso mogli obiskovati vrtca in šole, jih je skrbelo, kako bo poskrbljeno za uporabnike, če pa so bile na delovnem mestu, so lahko bile v stiski zaradi skrbi za svoje otroke.

[...] vmes me kličejo, mi pišeta moja otroka, ki sta sama doma (kratek čas, ker je mož skočil v službo), kasneje klic, da se tepeta??!! (StD5.12)

\section{Sklep in smernice za socialno delo $v$ izrednih razmerah}

Poročila o položaju socialnih služb v času pandemije covida-19 kažejo na nekatere podobnosti povsod po svetu. Slovenija ne odstopa od izkušenj, ki so jih imele socialne delavke glede nepripravljenosti na tako veliko naravno katastrofo, ki se 
je širila z veliko hitrostjo in povzročala veliko obolelih in umrlih. Vlade povsod po svetu so najprej obotavljajoče in nekonsistentno oblikovale ukrepe, vendar so se kmalu začele razlikovati tako po celovitosti ukrepov kot po upravljanju in obvladovanju institucionalnih sprememb (Dominelli, Harrikari, Mooney, Leskošek in Kennedy Tsunoda, 2020), še posebej pa po prepoznavanju socialnih vplivov epidemije in oblikovanju ustrezne socialne politike (Baptista in Marlier, 2020).

Naša raziskava kaže, da je bilo zavedanje o tem, da so vplivi epidemije tudi socialni, dokaj slabo. To je bila posledica več razlogov. Šele ta epidemija je pokazala šibkosti v zdravstvenem sistemu, majhnem številu zdravstvenega osebja in bolnišničnih postelj, saj je bilo zdravstvo že kmalu preobremenjeno. Na področju socialnega varstva pa je bila večina pozornosti namenjena domovom za stare ljudi in tam so se prav tako pokazali neprimernost in zastarelost institucij ter pomanjkanje kadra. Ministrstvo za delo, družino, socialne zadeve in enake možnosti je temu namenilo veliko pozornosti, zanemarilo pa drug del socialnovarstvenega sistema, to so programi in storitve za ljudi v socialnih stiskah.

Na podlagi rezultatov raziskave in literature (McFadden idr., 2020) ${ }^{5}$ sva oblikovali smernice za socialno delo v izrednih razmerah. Predstavljava jih v dveh medsebojno povezanih sklopih.

\section{Pomen organizacije v času izrednih razmer - izboljšanje delovnega okolja in delovnih razmer}

$\mathrm{V}$ času izrednih razmer ima velik pomen način organiziranja, saj ljudem določa (ne)dostopnost do ustrezne, takojšnje in strokovno utemeljene pomoči v obliki storitev in programov. Eden od pokazateljev neustreznosti slovenskega sistema je gotovo razkorak med številom obravnav nasilja $v$ domačem okolju in dejanskim povečanjem nasilja v času prvega in drugega vala epidemije. Način organiziranja socialnih služb naj temelji na čim večji strokovni avtonomiji, saj ta omogoča, da se socialne delavke avtonomno odločajo tako o metodah dela (s posameznikom, s skupino, zagovorništvo ipd.), ki so prilagojene posamezniku in posameznici, kot o načinu izvedbe (terensko delo, delo s skupnostjo, projektno delo ipd.). Temelji naj tudi na horizontalnem povezovanju zaposlenih in na demokratičnem vodenju, ker takšno vodenje in način povezovanja omogočata prožnost pri dogovarjanju in prilagajanju na razmere pa tudi hitro in učinkovito dogovarjanje med zaposlenimi. To veča tako dostopnost do storitev kot zadovoljstvo zaposlenih. V naši raziskavi se je pokazalo, da so tisti centri za socialno delo, ki so lahko delovali v skladu s to usmeritvijo, delovali bolj odprto za uporabnike, opaznega je bilo več proaktivnega in neposrednega socialnega dela z ljudmi.

Delodajalci morajo zagotoviti večjo prožnost delovnega časa, prostor za opravljanje dela, upoštevati potrebe po varstvu otrok in opravljanju drugih skrbstvenih nalog med pandemijo ali v drugih izrednih razmerah. $\mathrm{V}$ naši

COVID-19 Health and Social Care Workforce Study; Maj-July 2020, raziskava na vzorcu 3290 strokovnih delavk s področja zdravstva in socialnega varstva. Priporočila so bila izhodišče za oblikovanje smernic, določene teme sva dodali sami, glede na specifike ugotovitev za Slovenijo. 
raziskavi se je pokazalo, da je zelo pomembno iskati različne načine izvajanja dela skupaj z zaposlenimi. Kot dobra praksa se je pokazala individualno dogovarjanje vodstva z vsakim zaposlenim, saj je bilo na ta način možno ustvariti dogovore, ki so upoštevali potrebe posameznika in organizacije.

V času izrednih razmer je treba zagotoviti dodatna sredstva za več zaposlenih. Tako je možno zagotoviti opravljanje delovnih nalog in hkrati upoštevati specifične osebne okoliščine zaposlenih (npr. varstvo otrok, bivanje v gospodinjstvu z osebo, za katero je okužba rizična).

Potrebna so usposabljanja in razvijanja spretnosti za prevzemanje novih nalog $v$ času pandemije, nova znanja pa seveda lahko podprejo delovne procese tudi, ko je epidemije konec. $V$ primeru epidemije covida-19 so se centri za socialno delo prepočasi odzvali na nove okoliščine opravljanja dela na daljavo. Nujna je bila uporaba informacijsko-komunikacijske tehnologije, a zanjo ni bilo na voljo ustrezne opreme. Strokovne delavke, vključene v raziskavo, so pogrešale tudi ustrezna izobraževanja za uporabo videokonferenčnih aplikacij.

Ko je neposredno delo z osebnim stikom omejeno in je zaradi preprečevanja širjenja okužb treba prilagoditi število navzočih na delovnem mestu, je pomembno razvijati možnosti za delo od doma. Poleg ustrezne opreme za informacijsko-komunikacijsko tehnologijo je treba zagotoviti oddaljen dostop do podatkov. Možnost opravljanja dela od doma je pomembna tudi $v$ času drugih izrednih razmer (npr. poplava, potres, požar).

2. Skrb za povezanost med zaposlenimi in za komunikacijo (lahko tudi z uporabo informacijsko-komunikacijske tehnologije)

Povezanost med zaposlenimi je nujna, $\mathrm{k}$ temu pa pripomore redna in pogosta komunikacija. V kolektivu, kjer je povezanost večja in komunikacija redna, se zaposleni počutijo bolj podprte za opravljanje dela. To pripomore tudi k zavzetosti zaposlenih in vpletenosti v delovne procese.

Delodajalci so odgovorni za zagotavljanje smernic za delo in posodabljanje informacij. Pomembno je, da so sporočila jasna, saj tako zmanjšamo negotovost in zmedo. $V$ naši raziskavi so strokovne delavke poročale tako o dobrih kot o slabih praksah. Poročale so o rednih in osebnih srečanjih, o skrbi, ki jo je vodstvo namenilo temu, da so bile potrebe ljudi ustrezno obravnavane, in so se angažirale tudi v lokalni skupnosti, da bi zagotovile čim večje upoštevanje celovitosti potreb ljudi. Poročale pa so tudi o avtoritarnem vodenju, ki je temeljilo na prepovedih in onemogočanju stikov, brez upoštevanja različnosti potreb tako zaposlenih kot uporabnic in uporabnikov storitev centra za socialno delo. Nekateri vodje so samo posredovali navodila, ki so jih prejemali z ministrstva ali Nacionalnega inštituta za javno zdravje, brez prilagajanja na razmere njihovega centra za socialno delo in brez pogovora o načinu izvajanja. Teh navodil je bilo veliko, pogosto so si nasprotovala, včasih so bila tudi zastarela, to pa je povzročalo zmedo in več težav.

Pomembno je, da vodje omogočajo predvsem čim bolj nemoteno delo tudi $\mathrm{v}$ izrednih razmerah, pri tem pa morajo iskati inovativne načine dela $\mathrm{v}$ tesni komunikaciji z zaposlenimi. Zaposleni se $\mathrm{v}$ teh razmerah spoprijemajo tudi s hudimi situacijami pri opravljanju svojega dela, na primer, smrtjo, hudim nasi- 
ljem, nakopičenimi konflikti, in potrebujejo veliko podpore pri svojem delu. Skrb za zaposlene vodstvo izraža tudi z zagotavljanjem podpore v obliki supervizije, intervizije in timskega dela.

Rezultati raziskave so pokazali tudi na kopičenje dela pri zaposlenih, ki niso imeli obveznosti glede šolanja otrok, zato so prevzemali več dela, posledice tega pa so lahko izgorevanje, kopičenje nezadovoljstva in tudi razhajanja $\mathrm{v}$ kolektivu. Vodstvo naj bo pozorno na ustrezno razporejanje dela, omogočanje koriščenja prostih dni in letnega dopusta ter počitka.

Resno je treba vzeti tudi skrb zaposlenih glede okužb. Poslušati njihove skrbi in sprejeti razumne ukrepe. V raziskavi se je pokazala stiska tistih zaposlenih, ki so se bali prenosa okužbe zaradi nege starejših, otrok z zdravstvenimi problemi ali zaradi lastnih zdravstvenih težav, ki bi jih okužba še povečala. Ustrezna rešitev sta lahko delo na daljavo in delo od doma ob ustrezni opremljenosti z informacijsko-komunikacijsko tehnologijo ter ob podpori vodstva in sodelavk za krajše obdobje.

\section{Viri}

Amadasun, S. (2020). Social work and COVID-19 pandemic: an action call. International Social Work, 63(6), 753-756.

Banks, S., Cai, T., Jonge, E. de, Shears, S., Shum, M., Sobočan, A. M., Strom, K., Úriz, M. J., \& Weinberg, M. (2020). Practising ethically during COVID-19: social work challenges and responses. International Social Work, 63(5), 569-583.

Baptista, E., \& Marlier, E. (2020). Access to essential servicies for people with low incomes in Europe: an analysis of policies in 35 counries. Brussels: Europen Commision.

BASW (b.d.). CPD Guidance on social work roles undertaken during disaster. Prisobljeno 26. 7. 2021 s https://www.basw.co.uk/system/files/resources/181086\%20CPD\%20guidance\%20on\%20disaster\%20social\%20work\%20V2.pdf

Berg-Weger, M., \& Morley, J. E. (2020). Loneliness and social isolation in older adults during the covid-19 pandemic: implications for gerontological social work. The Journal of Nutrition, Health \& Aging, 24(5), 456-458.

Dominelli, L., Harrikari, T., Mooney, J., Leskošek, V., \& Kennedy Tsunoda, K. (ur.) (2020). Covid-19 and social work: a collection of country reports. Pridobljeno 1. 6. $2021 \mathrm{~s} \mathrm{https://}$ www.iassw-aiets.org/covid-19/5369-covid-19-and-social-work-a-collection-of-country-reports/

Global definition of social work (b.d). Pridobljeno 15. 6. 2021 s http://ifsw.org/get-involved/ global-definition-of-social-work/

Harrikari, T., Romakkaniemi, M., Tiitinen, L., \& Ovaskainen, S. (2021). Pandemic and social work: exploring finnish social workers' experiences through a SWOT analysis. British Journal of Social Work, 00, 1-21. doi: 10.1093/bjsw/bcab052.

Kerč, P., Krohne, N., Šraj Lebar, T., \& Štirn, M. (2021). Ocena potreb po psihosocialni podpori v drugem valu epidemije COVIDA-19. Pridobljeno 23. 7. $2021 \mathrm{~s}$ http://www.dps.si/wp-content/uploads/2021/03/Ocena-potreb-po-psihosocialni-podpori.pdf

Lobnik, M. (2020). Priporočila Zagovornika načela enakosti glede nadaljnjih ukrepov za blaženje posledic epidemije Covid-19 z namenom preprečevanja in odprave diskriminacije. Pismo Vladi RS. Pridobljeno 20. 7. 2021 s http://www.zagovornik.si/wp-content/ uploads/2020/04/Priporo\%C4\%8Dila-Zagovornika-na\%C4\%8Dela-enakosti-glede-nadaljnjih-ukrepov-za-bla\%C5\%BEenje-posledic-epidemije-Covid-19-z-namenom-prepre\%C4\%8Devanja-in-odprave-diskriminacije.pdf 
McFadden, P., Gillen, P., Moriarty, J., Mallett, J., Schroder, H., Ravalier, J., Manthorpe, J., Harron, J., \& Currie, D. (2020). COVID-19 health and social care workforce study May-July 2020. Pridobljeno 24. 2. 2021 s https://www.sabin.scot.nhs.uk/wp-content/uploads/2020/11/HSC-Survey-Executive-Summary.pdf

Nasilje in epidemija covida-19 (b.d.). Pridobljeno 21. 7. $2021 \mathrm{~s} \mathrm{https://www.drustvo-dnk.si/o-}$ -nasilju/nasilje-in-covid-19.html

Pink, S. Ferguson, H., \& Kelly, L. (2020). Child protection social work in COVID-19: reflections on home visits and digital intimacy. Antropology in Action, 27(3), 27-30.

Plesničar, M., Drobnjak, M., \& Filipčič, K. (2020). Kriminaliteta v času Covid-19. Ljubljana: Inštitut za kriminologijo pri Pravni fakulteti Univerze v Ljubljani.

Rode, N., Zidar, R., Lamovšek, V., Škerjanc, J., \& Urek, M. (2010). Socialno delo v primeru naravnih in drugih nesreč. V M. Zorn, B. Komac, M. Pavšek, \& P. Pagon (ur.), Naravne nesreče 1: od razumevanja do upravljanja (str. 349-355). Ljubljana: Založba ZRC.

Ronchi, K., \& Majdič, N. (2021). Vpliv epidemije na socialne razmere prebolelih po Covid-19. Rehabilitacija, 20(supl. 1), 44-48.

Saltzman, I. Y., Hansel, T. C., \& Bordnick, P. S (2020). Loneliness, isolation, and social support factors in post-COVID-19 mental health. Psychological Trauma: Theory, Research, Practice, and Policy, 12(S1), S55-S57. Pridobljeno 4. 4. 2021 s http://dx.doi.org/10.1037/ tra0000703

SURS (2021). Dohodek, revščina in socialna izključenost. Pridobljeno 26. 7. 2021 s https:// www.stat.si/StatWeb/Field/Index/10/39

Walter-McCabe, H. A. (2020). Coronavirus pandemic calls for an immediate social work response. Social Work in Public Health, 35(3), 69-72.

ZRSZ (2021). Mesečne informacije, marec 2021. Pridobljeno 26. 7. 2021 s http://www.vss. sc-sg.si/files/2021/04/MI_2021_3.pdf 
